\title{
UČINKOVITOST KAO UVJET VAŽENJA U KELSENOVOJ OPĆOJ TEORIII NORMI
}

Izv. prof. dr. sc. Luka Burazin*

UDK: 340.142 Kelsen

340.132.6.01

DOI: 10.3935/zpfz.70.23.05

Izvorni znanstveni rad

Primljeno: svibanj 2020.

Prema Kelsenu postoje dva (činjenična) uvjeta pod kojima se može reći da se norme treba pridržavati, a ako je se ne pridržava, da je treba primjenjivati, tj. da norma postoji ili važi. Ti su uvjeti sljedeći: 1) činjenica da je norma postavljena (i da nije derogirana) i 2) činjenica da je norma učinkovita ili da je moguće da bude učinkovita. U radu se usredotočujem na drugi od dvaju (činjeničnih) uvjeta važenja. Osnovni je cilj rada rekonstruirati i kritički raščlaniti učinkovitost kao uvjet važenja u Kelsenovoj Općoj teoriji normi $u$ svjetlu Kelsenova novouvedenog razlikovanja između uvjetnog i potpunog važenja norme i dinamičkog aspekta pravnog poretka. Osim toga, u radu nastojim sustavno objasniti učinkovitost kao uvjet važenja općih i pojedinačnih pravnih normi, uzimajući u obzir vremenski aspekt važenja, tj. trenutke u kojima norma stječe i gubi važenje i vremenski luk $u$ kojemu je važeća (u kojemu postoji).

Ključne riječi: Hans Kelsen, važenje, postojanje, učinkovitost, pravni poredak

\section{UVOD}

U Općoj teoriji normi, kao i u svojim ranijim radovima, Kelsen koristi termin "važenje" u smislu "specifičnog postojanja norme"1, koje se "sastoji u tome da

Dr. sc. Luka Burazin, izvanredni profesor Pravnog fakulteta Sveučilišta u Zagrebu, Trg Republike Hrvatske 14, 10000 Zagreb; lburazn@pravo.hr;

ORCID: orcid.org/0000-0002-2437-8871

1 Kelsen, H., General Theory of Norms, preveo M. Hartney, Clarendon Press, Oxford, 1991. [1979.], str. 2 i 28. 
se norme treba pridržavati, a ako je se ne pridržava, da je treba primjenjivati". ${ }^{2}$ 'Važenje' se odnosi i na opće i na pojedinačne norme, bile one kategoričke ili hipotetičke. Dok su opće norme one koje određuju "kao obvezno neko opće određeno ponašanje" , pojedinačne norme su one koje određuju "kao obvezno jednokratno, pojedinačno određeno ponašanje". ${ }^{4}$ Kategoričke su norme one koje "određuju da je neko ponašanje bezuvjetno obvezno", a hipotetičke (ili uvjetne) one koje "određuju da je neko ponašanje obvezno samo pod određenim uvjetima". ${ }^{5}$

Prema Kelsenu osnovni tip pravne norme je opća (hipotetička) pravna norma, koja ima sljedeću formulaciju:

'Ako nadležni organ primjene prava - osobito sud - utvrdi da se neka osoba ponašala na određeni način - npr. da je počinila krađu - organ primjene prava treba postaviti pojedinačnu normu kojom se određuje da se protiv te osobe treba usmjeriti određen akt prisile - npr. zatvaranje (tj. prisilno lišavanje slobode). ${ }^{6}$

Dakle, za Kelsena postoje samo opće sankcionirajuće pravne norme, dok su opće norme o ponašanju (to jest "one koje propisuju ponašanje kojim se izbjegava sankcija"), ako se uzme da one postoje, "implicirane u sankcionirajućoj normi" (dalje u tekstu: implicitne norme o ponašanju). ${ }^{7}$ Iz ovoga shvaćanja proizlazi da su neposredni adresati općih pravnih normi samo "pojedinci koji su ovlašteni" (a obično i obvezani) "narediti u konkretnom slučaju i izvršiti akte prisile koji služe kao sankcije" (naime, suci ili upravna tijela te organi izvršenja), a da su "tek posredni adresati općih pravnih normi ... pojedinci čije je ponašanje uvjet za tim normama određene akte prisile". ${ }^{8}$

2 Ibid., str. 3.

3 Ibid., str. 7.

4 Ibid.

5 Ibid., str. 19.

6 Ibid., str. 53. Ili: "Ako nadležni organ primjene prava (osobito sud) utvrdi da se u konkretnom slučaju ostvarilo činjenično stanje koje je apstraktno određeno u općoj pravnoj normi, nadležni sud treba postaviti pojedinačnu normu kojom se određuje da je obvezan konkretan akt prisile koji odgovara aktu prisile apstraktno određenom u općoj pravnoj normi”. Vidi ibid., str. 140 - 141. U pogledu nedoumica koje proizlaze iz teksta drugonavedene formulacije opće norme vidi Navarro, P. E., The Efficacy of Constitutional Norms, u: d'Almeida, L. D.; Gardner, J.; Green, L. (ur.), Kelsen Revisited. New Essays on the Pure Theory of Law, Hart Publishing, Oxford and Portland, Oregon, 2013., str. 96.

7 Kelsen, op. cit. u bilj. 1, str. 142. Vidi i ibid., str. 56 - 57 i 133 - 134.

8 Ibid., str. 52. 
U dinamičnom sustavu normi kao što je pravni poredak, koji je obilježen kontinuiranim procesom normativne proizvodnje ${ }^{9}$, važenje (ili postojanje) norme ima vremensku dimenziju, to jest postoji trenutak u kojemu norma postaje važeća (ili postojeća) i trenutak u kojemu prestaje biti važeća (ili postojeća). Vrijeme između tih dvaju trenutaka je vrijeme važenja (ili postojanja) norme.

Prema Kelsenu postoje dva (činjenična) uvjeta pod kojima se može reći da se norme treba pridržavati, a ako je se ne pridržava, da je treba primjenjivati, tj. da norma postoji ili važi. Ti su uvjeti sljedeći: 1) činjenica da je norma postavljena (i da nije derogirana) i 2) činjenica da je norma učinkovita ili da je moguće da bude učinkovita. ${ }^{10}$

Kada je riječ o uvjetu normativne proizvodnje (koji uključuje ne samo akte postavljanja norme nego i akte voljnog uklanjanja normi iz sustava normi), norma stječe važenje (postojanje) u trenutku kada je postavljena. To se odnosi i na opće i na pojedinačne norme. Opće norme postaju važeće (postojeće) u trenutku kada su postavljene, bilo voljno (npr. kada ih postavi zakonodavac) ili uobičajenjem. Pojedinačne norme koje su postavljene u skladu s općim normama postaju važeće (postojeće) u trenutku kada ih se voljno postavi (npr. kada ih postavi sudac). Ako pojedinačna norma nije postavljena u skladu s općom pravnom normom, ona postaje važeća na temelju načela res iudicata (ako je navedeno načelo na snazi u dotičnom pozitivnom pravnom poretku). ${ }^{11}$ I opće i pojedinačne norme gube svoje važenje u trenutku kada ih se derogira, u smislu da se njihovo važenje ukine drugom normom (npr. derogirajućom normom zakonodavca u slučaju opće norme i derogirajućom odlukom višeg suda u slučaju odluke nižega suda). ${ }^{12}$ Osim toga, pravna norma gubi važenje istekom vremena važenja za koje je postavljena ${ }^{13}$ ili, kada je riječ o pojedinačnoj pravnoj normi, u trenutku njezina izvršenja. ${ }^{14}$

9 Guastini, R., Le fonti del diritto, A. Giuffrè editore, Milano, 2010., str. 435.

10 Kelsen, op. cit. u bilj. 1, str. 140.

11 Ibid., str. $248-249$.

12 Ibid., str. $106-114$.

13 Ibid., str. 106.

14 Ibid., str. 110. To se, očito, odnosi samo na one pojedinačne pravne norme koje određuju izvršenje akta prisile. No, time se otvara zanimljivo pitanje u pogledu pojedinačnih normi kojima se određuje da se ne smije izvršiti nikakav akt prisile (npr. sudska odluka kojom se odbija tužiteljev tužbeni zahtjev ili kojom se optuženik oslobađa optužbe). Prema jednom (manje uvjerljivom) tumačenju čini se da bi, paradoksalno, takve pojedinačne norme $u$ istome trenutku, tj. $u$ trenutku njihova postavljanja, i stjecale i gubile važenje. Prema drugom (uvjerljivijem) tumačenju, s obzirom na to da su takve pojedinačne norme, prema Kelsenu, zapovijedi organima 
Kada je riječ o učinkovitosti kao uvjetu važenja, Kelsen tvrdi da norma (opća i pojedinačna) postaje važećom u trenutku kada je postavljena pod uvjetom da je moguće da bude učinkovita te da norma (opća i pojedinačna) prestaje važiti u trenutku od kojega više ne postoji mogućnost da bude učinkovita i, dodatno, da opća norma prestaje važiti u trenutku od kojega više nije stvarno učinkovita (desuetudo ili izobičajenje). ${ }^{15}$

U radu se usredotočujem na drugi od dvaju (činjeničnih) uvjeta važenja. Osnovni je cilj rada rekonstruirati i kritički raščlaniti učinkovitost kao uvjet važenja u Kelsenovoj Općoj teoriji normi u svjetlu Kelsenova novouvedenog razlikovanja između uvjetnog i potpunog važenja norme i dinamičkog aspekta pravnog poretka. Osim toga, u radu nastojim sustavno objasniti učinkovitost kao uvjet važenja općih i pojedinačnih pravnih normi, uzimajući u obzir vremenski aspekt važenja, tj. trenutke u kojima norma stječe i gubi važenje i vremenski luk u kojemu je važeća (u kojemu postoji).

\section{POJAM UČINKOVITOSTI}

Prema Kelsenu učinkovitost može biti predikat pravnih normi i pravnih poredaka. ${ }^{16}$ Pravna norma je učinkovita ako se norme "stvarno pridržava, i ako se primjenjuje kada je se ne pridržava". ${ }^{17}$ Pravni poredak je učinkovit ako "se njegovih normi koje zapovijedaju određeno ponašanje stvarno pridržava, i ako se one primjenjuju kada ih se ne pridržava". ${ }^{18}$ Na prvi se pogled može učiniti da ova tvrdnja u pogledu učinkovitosti normi predstavlja izmjenu Kelsenova shvaćanja iz Opće teorije prava i države. Ondje je tvrdio da se učinkovitost pravnih normi sastoji ponajprije u tome da ih organi primjene prava primjenjuju, a, podredno,

izvršenja da se suzdrže od izvršavanja akata prisile u određenim slučajevima, one bi izgubile važenje u trenutku u kojemu bi nestala mogućnost da budu prekršene (od strane organa izvršenja), primjerice, kada osoba koja je oslobođena optužbe umre.

15 Ibid., str. 139 - 140.

16 Vidi ibid., str. 138. Ipak, s jednom ogradom, s obzirom na to da, prema Kelsenu, učinkovitost zapravo nije svojstvo norme nego ponašanja. "Pridržavanje norme nije svojstvo norme, nego određenog činjeničnog ponašanja, i stoga činjenice. To ponašanje čini pridržavanje norme - ono ima svojstvo pridržavanja norme - ako odgovara normi kojom se to ponašanje određuje kao obvezno." (str. 219). Ista se tvrdnja nalazi u Kelsen, H., General Theory of Law and State, preveo Anders Wedberg, Cambridge, Massachusetts, Harvard University Press, 1945., str. 40.

17 Kelsen, op. cit. u bilj. 1, str. 3.

18 Ibid., str. 138. 
u tome da ih se građani pridržavaju ${ }^{19}$ Međutim, budući da Kelsen nije izmijenio svoja shvaćanja o odnosu između tzv. primarnih normi (sankcionirajuće norme u Kelsenovoj teoriji) i tzv. sekundarnih normi (norme o ponašanju u Kelsenovoj teoriji), čini se razumnim pretpostaviti da inverzija pridržavanja i primjene prava u njegovoj definiciji učinkovitosti počiva na činjenici da je uvjet za primjenu prava njegovo kršenje (preciznije, nastup činjeničnog stanja koje je uvjet za akt prisile određen u općoj normi), pa je norma učinkovita: 1) ako se norme pridržava i 2) ako se primjenjuje kada je se ne pridržava (tj. kada je se krši).

Kelsen definira pridržavanje, kršenje i primjenu norme povlačeći vezu između razlikovanja pridržavanja (ili kršenja) i primjene norme s jedne strane, i razlikovanja funkcije zapovijedanja (ili zabranjivanja) i funkcije ovlašćivanja s druge strane..$^{20}$

Osoba čije je ponašanje uvjet za sankciju određenu u pravnoj normi krši pravo (...). Osoba čije ponašanje izbjegava pravnu sankciju pridržava se prava (...). Tužitelj ili državni odvjetnik koji zahtijeva od suca da odredi sankciju, i sudac koji odredi sankciju, i organ izvršenja koji izvršava određenu sankciju, primjenjuju pravo. ${ }^{21}$

Konkretno, kada je riječ o primjeni norme, norma se smatra primijenjenom, i stoga učinkovitom, ako je postavljena pojedinačna kategorička norma na temelju upotrebe ovlasti dodijeljene općom normom. Kelsen identificira dva slučaja primjene norme: 1) kada ovlašteni sud (ili upravni organ) utvrdi da je konkretno činjenično stanje podvedivo pod činjenično stanje apstraktno određeno u općoj normi, postavi pojedinačnu normu kojom zapovijeda ovlaštenom organu izvršenja da izvrši konkretan akt prisile, i kada ovlašteni organ izvršenja izvrši taj akt prisile; i 2) kada ovlašteni sud (ili upravni organ) utvrdi da konkretno činjenično stanje koje je podvedivo pod činjenično stanje apstraktno određeno u općoj normi ne postoji i postavi pojedinačnu normu kojom se određuje da se ne smije izvršiti nikakav akt prisile (tj. odbije tužiteljev zahtjev ili oslobodi

\footnotetext{
19 Kelsen, op. cit. u bilj. 16, str. $61-62$.

20 Kelsen, op. cit. u bilj. 1, str. 104.

${ }^{21}$ Ibid., str. 105.
} 
optuženika). ${ }^{22}$ Neovlašteno postavljanje pojedinačne kategoričke norme ne predstavlja primjenu prava, ono je ništetno, pravno nepostojeće. ${ }^{23}$

Dakle, zapovijedi se pridržava ili ih se krši, a ovlasti se primjenjuju. Međutim, Kelsen kaže da je sucima, uz to što su "zakonom ovlašteni primjenjivati opće pravne norme na konkretne slučajeve"24, "u pravilu i zapovjeđeno" 25 da ih primjenjuju. Prema tome, "sudac krši dužnosti svoje službe ako se suzdrži od upotrebe svoje vlasti u konkretnom slučaju". ${ }^{26} \mathrm{I}$, treba dodati, sudac se pridržava dužnosti svoje službe ako upotrijebi svoju vlast u konkretnom slučaju. To jasno proizlazi iz odlomaka u kojima Kelsen govori o individualizaciji opće norme. ${ }^{27}$ Stoga, osim posrednih adresata općih normi, tj. pojedinaca čije je ponašanje uvjet za akte prisile određene tim normama, normi se pridržavaju ili ih krše i organi ovlašteni primjenjivati pravo u slučajevima kada im je istodobno zapovjeđeno da ga primjenjuju.

Kelsen pravi razliku između objektivnog i subjektivnog pridržavanja i kršenja, to jest između onoga što se još naziva ciljnom i motivacijskom (ili psihološkom) učinkovitošću. ${ }^{28}$ Dok je dovoljan uvjet objektivnog pridržavanja (ili kršenja) puko odgovaranje (ili neodgovaranje) stvarnog ponašanja adresata norme normativnom sadržaju norme, nužan je uvjet subjektivnog pridržavanja (ili kršenja) svjesno i voljno ponašanje adresata norme koje odgovara (ili ne odgovara) normativnom sadržaju norme. ${ }^{29}$ Prema Kelsenovu mišljenju, "kada se smatra

22 Vidi ibid., str. 52 - 53 i 140 - 141. U Čistoj teoriji prava, 2. izd., Kelsen nije identificirao drugi slučaj primjene norme. Da "normu pravni organi (osobito sudovi) primjenjuju ... znači da se sankcija u konkretnom slučaju izriče i izvršava”. Vidi Kelsen, H., Pure Theory of Law, 2. izd., preveo Max Knight, University of California Press, Berkeley - Los Angeles, 1967., str. 11.

23 Kelsen, op. cit. u bilj. 1, str. 102.

24 Ibid., str. 103.

25 Ibid.

26 Ibid.

27 Vidi, primjerice, ibid., str. 240: “Jer čak i ako sudac Körner samome sebi uputi zapovijed 'Ja, sudac Körner, trebam postaviti pojedinačnu normu "Maier treba u zatvor"', pa je ta pojedinačna norma važeća, sudac Körner iz nekoga razloga ipak može propustiti pridržavati se te norme, tj. propustiti postaviti pojedinačnu normu "Maier treba u zatvor'".

28 Grabowski, A., Juristic Concept of the Validity of Statutory Law. A Critique of Contemporary Legal Nonpositivism, prevela Małgorzata Kiełtyka, Springer, Berlin, Heidelberg, 2013., str. 335. Vidi i Burazin, L., The Concept of Law and Efficacy, u: Sellers, M.; Kirste, S. (ur.), Encyclopedia of the Philosophy of Law and Social Philosophy, Springer, Dordrecht, 2017.

29 Kelsen, op. cit. u bilj. 1, str. 57 i 37. 
da se je norme pridržavalo ili da je se primjenjivalo, nikakva se pozornost ne poklanja motivu koji je doveo do ponašanja koje čini pridržavanje ili primjenu norme" ${ }^{30}$ Prema tome, motiv nije relevantan za ocjenu je li norma učinkovita ili nije. Iako, naravno, kada je riječ o sucima, s obzirom na to da su oni ovlašteni, a istodobno obično i obvezani primjenjivati pravne norme, njihovo će ponašanje u pravilu činiti subjektivno pridržavanje ili kršenje norme, tj. oni će se u pravilu svjesno i voljno pridržavati norme koju primjenjuju.

Drugo razlikovanje koje Kelsen koristi u pogledu učinkovitosti normi ono je između neposrednog i posrednog pridržavanja i kršenja (i primjene) normi. Za Kelsena samo se pojedinačnih kategoričkih normi može pridržavati ili ih kršiti (ili primjenjivati) neposredno, dok se općih (hipotetičkih i kategoričkih) ${ }^{31}$ normi i pojedinačnih hipotetičkih normi može pridržavati ili ih kršiti (ili primjenjivati) samo posredno. ${ }^{32}$ Međutim, Kelsen nije posve jasan u pogledu toga što to neke vrste normi čini podložnima samo posrednom pridržavanju ili kršenju, što pak stvara određene dvojbe u pogledu toga o kojim je zapravo vrstama normi riječ. Naime, on izrijekom kaže da je norma podložna samo posrednom pridržavanju ili kršenju kada “je ponašanje koje se može okarakterizirati kao pridržavanje ili kršenje norme moguće tek nakon konkretnog ostvarenja uvjeta koji je apstraktno određen u općoj normi" i daje primjer (moralne) norme "Ako netko da obećanje, treba ga se držati”. ${ }^{33}$ Ta je norma, kaže Kelsen, podložna pridržavanju ili kršenju "tek nakon što određena osoba $A$ da određeno obećanje - npr. da će platiti 1000 - određenoj osobi $B$ " ${ }^{34}$ Međutim, ako je tomu tako, ako je ispunjenje uvjeta pod kojim je određeno ponašanje obvezno ono što normu čini podložnom samo posrednom pridržavanju ili kršenju, onda se čini da se i opće kategoričke norme može pridržavati ili je se kršiti neposredno. ${ }^{35} \mathrm{No}$, to proturječi gorenavedenom

30 Ibid., str. 138.

31 Ustvari, Kelsen kaže “opća norma (bilo kategorički ili hipotetički važeća)". Ibid., str. 46. Međutim, s obzirom na to da Kelsen tvrdi da sve norme (i kategoričke i hipotetičke norme, tj. i one kojima se određuje da je određeno ponašanje obvezno bezuvjetno i one kojima se određuje da je određeno ponašanje obvezno samo pod određenim uvjetima) mogu biti važeće samo uvjetno (hipotetički), tj. da mogu biti važeće samo pod uvjetom da ih se može pridržavati (vidi ibid., str. 19 - 21), čini se da Kelsen ovdje misli na kategoričke i hipotetičke norme, a ne na kategoričko ili hipotetičko važenje normi.

32 Vidi ibid., str. 46, 50 i $220-221$.

33 Ibid., str. 46.

34 Ibid.

35 To se tumačenje može poduprijeti onime što Kelsen kaže na drugome mjestu: "Neposredno se pridržavati norme ili je neposredno kršiti moguće je samo kada je riječ 
izričitom Kelsenovu shvaćanju prema kojem se samo pojedinačnih kategoričkih normi može pridržavati ili ih kršiti neposredno, dok se to u slučaju općih (i kategorički i hipotetičkih) normi može činiti samo posredno. Ustvari, iz niza primjera koje Kelsen navodi kako bi objasnio proces na temelju kojega se norme pridržava ili je se primjenjuje ${ }^{36}$, i nužnosti postupka individualizacije (općih) normi ${ }^{37}$ (o čemu će biti riječi u idućem poglavlju), slijedi da ono što normu čini podložnom samo posrednom pridržavanju (i kršenju) ili primjeni nije (barem u smislu nužnoga uvjeta) ispunjenje uvjeta pod kojim je određeno ponašanje obvezno, nego potreba postavljanja odgovarajuće pojedinačne kategoričke norme. Naime, prema Kelsenovu mišljenju, da bi bilo moguće primijeniti (i, u pravilu, pridržavati se) opće norme koja obvezuje nadležni sud da postavi pojedinačnu normu kojom se određuje izvršenje akta prisile, treba postaviti pojedinačnu kategoričku normu 'Ti, nadležni sude, trebaš postaviti pojedinačnu normu'.

Dakle, kad god je za pridržavanje ili primjenu norme nužno postaviti odgovarajuću pojedinačnu kategoričku normu, može se reći da se prve norme može pridržavati ili je kršiti samo posredno, tj. da je se može pridržavati ili je kršiti samo posredstvom odgovarajuće pojedinačne kategoričke norme. I tome je tako i kada je riječ o općim (hipotetičkim i kategoričkim) normama i kada je riječ o pojedinačnim hipotetičkim normama. ${ }^{38}$ Neposredno se pridržavajući pojedinačne kategoričke norme, ili je neposredno kršeći ili primjenjujući, pojedinac se istodobno posredno pridržava pojedinačne hipotetičke norme ili opće (kategoričke ili hipotetičke) norme, posredno je krši ili primjenjuje.

Konačno, Kelsen navodi da je učinkovitost stupnjevita u smislu da se normu može smatrati učinkovitom ne samo kada se nje uvijek pridržava ili je se primjenjuje (pod uvjetom da je se može i kršiti i ne primjenjivati) nego i kada se nje u cjelini gledano pridržava ili je se primjenjuje. ${ }^{39}$ Konkretno, može se reći da je norma, prema Kelsenovoj teoriji, učinkovita u sljedećim slučajevima: 1) ako se nje uvijek pridržava, pa sudovi (ili drugi organi primjene prava) nikada ne dođu u situaciju da je primjene ${ }^{40}$; 2) ako se nje ponekad pridržava i ponekad

o bezuvjetnoj (kategoričkoj) normi, a ne o uvjetnoj (hipotetičkoj), jer sve dok nije ispunjen uvjet, ne može biti riječi o pridržavanju ili kršenju”. Ibid., str. 220 - 221.

36 Vidi primjere dane u Kelsen, op. cit. u bilj. 1, str. 46 - 48 (za opće hipotetičke i kategoričke moralne norme), 53 - 54 (za opće i pojedinačne hipotetičke pravne norme).

37 Vidi ibid., str. 50 i 226. Čini se da iz primjera koji Kelsen daje u ibid., str. 53 proizlazi da i pojedinačne hipotetičke norme, da bi bile primijenjene, trebaju biti individualizirane (postavljanjem odgovarajućih pojedinačnih kategoričkih normi).

38 Vidi primjere na koje se upućuje u bilj. 36.

39 Kelsen, op. cit. u bilj. 1, str. 138 - 139.

40 Ibid., str. 141. 
je se krši, ali je se u cjelini gledano primjenjuje u slučajevima njezina kršenja i 3) ako se nje nikada ne pridržava, ali je se u cjelini gledano primjenjuje. ${ }^{41}$

Budući da se, prema Kelsenu,

[o]pća norma može smatrati učinkovitom čak i ako se nikada ne primijeni, no samo ako sudovi nikada ne dolaze u situaciju da utvrde konkretno činjenično stanje koje je uvjet za sankcije i koje je apstraktno određeno u općoj normi, jer takvo činjenično stanje uopće ne nastupa ili ne nastupa više, premda je i dalje moguće da nastupi ${ }^{42}$,

čini se da Kelsen isključuje mogućnost da se normu smatra učinkovitom ako se nje u cjelini gledano pridržava, ali je se nikada ne primijeni. Nadalje, iako Kelsen to ne kaže izrijekom, čini se da on isključuje i mogućnost da se normu smatra učinkovitom ako se nje u cjelini gledano pridržava, ali je se u cjelini gledano ne primjenjuje u slučajevima njezina kršenja. Potpora za takvo tumačenje može se pronaći u Kelsenovoj tvrdnji, prema kojoj

[o]dgovor na pitanje je li opća norma učinkovita ne ovisi o zbiljskom pridržavanju norme koju smo nazvali ‘sekundarnom' normom (tj. o ponašanju kojim se izbjegava sankcija), nego o sudskom utvrđenju da postoji činjenično stanje koje je uvjet za sankciju. ${ }^{43}$

Naravno, sa samo jednom iznimkom, naime "ako sudovi nikada ne dolaze u situaciju da utvrde konkretno činjenično stanje koje je uvjet za sankcije i koje je apstraktno određeno u općoj normi". ${ }^{4}$

\section{UČINKOVITOST KAO UVJET POČETKA VAŽENJA NORME}

Prema Kelsenu učinkovitost nije uvjet važenja norme u smislu da norma mora biti učinkovita da bi bila važeća. Ako se o nekoj normi govori kao učinkovitoj ili neučinkovitoj, to pretpostavlja da je norma već postala važeća "s obzirom na to da norma postaje važeća prije nego je učinkovita i može postati učinkovita tek nakon što postane važeća" ${ }^{45}$ Međutim, normu se ne može smatrati važećom ako određuje nešto čega se je objektivno, prema prirodnim zakonima, nemoguće pridržavati ili to kršiti s obzirom na to da je u prirodi prava da se obraća

\footnotetext{
${ }^{41}$ Za krajnje posljedice učinkovitosti koje, čini se, proizlaze iz Kelsenove doktrine o utemeljujućem karakteru sudskih odluka vidi Navarro, op. cit. u bilj. 6, str. 97 - 98.

42 Kelsen, op. cit. u bilj. 1, str. 141. Kurziv u izvorniku.

43 Ibid., str. 141.

44 Ibid. Kurziv moj.

45 Ibid., str. 140.
} 
zbilji koja s njime (to jest s važenjem prava) nije identična, kako bi utjecala na tu zbilju. ${ }^{46}$ Stoga, uvjet početka važenja norme nije njezina učinkovitost, nego samo mogućnost njezine učinkovitosti. ${ }^{47}$

Budući da je u Općoj teoriji normi Kelsen uveo razlikovanje između uvjetnog i potpunog važenja norme, treba objasniti na što se svodi mogućnost učinkovitosti norme kao uvjet važenja u odnosu na te dvije vrste ili, kako ćemo uskoro vidjeti, faze važenja. Novo Kelsenovo razlikovanje odnosi se i na opće i na pojedinačne norme te uzima u obzir dinamični aspekt pravnog poretka i učinkovitost kao uvjet pravnog važenja.

Pravna norma je važeća čim je postavljena. No, prema Kelsenu, to je samo uvjetno važenje norme s obzirom na to da je norma važeća samo pod uvjetom da se nje moguće pridržavati ili je kršiti, i primjenjivati je ili ne primjenjivati. ${ }^{48}$ Dakle, uvjet važenja norme je mogućnost da bude učinkovita u smislu mogućnosti da se nje pridržava ili je se krši, i primjenjuje je ili ne primjenjuje. ${ }^{49} \mathrm{Kada}$ je riječ o općim normama, dovoljno je, naravno, da je općenito moguće da se norme pridržava ili je se krši, i primjenjuje je ili ne primjenjuje, i da nije nužno nemoguće da je se pridržava ili je se krši, i primjenjuje je ili ne primjenjuje; to jest, nije nužno da se u svakom konkretnom slučaju opće norme može pridržavati ili je kršiti, i primjenjivati je ili ne primjenjivati. ${ }^{50}$ Kao što je rečeno, normu se ne može smatrati važećom ako određuje nešto što se, prema prirodnim zakonima, ni u kojem slučaju ne može dogoditi ili što se mora dogoditi (npr. 'Ljudi trebaju živjeti vječno' i 'Ljudi trebaju umrijeti'). ${ }^{51}$ Pravna norma je potpuno važeća ako stvarno postoji mogućnost da se nje neposredno pridržava ili je se krši, primjenjuje je se ili ne primjenjuje. Stoga se može reći da su samo pojedinačne kategoričke norme potpuno važeće od trenutka njihova postavljanja, a da su sve ostale vrste normi (pojedinačne hipotetičke norme i opće kategoričke i hipotetičke norme) potpuno važeće od trenutka postavljanja potrebne pojedinačne kategoričke norme.

46 Kelsen, op. cit. u bilj. 22, str. 213 i Kelsen, op. cit. u bilj. 1, str. 59.

47 Učinkovitost je očito nužan uvjet važenja običajnih normi.

48 Kelsen, op. cit. u bilj. 1, str. 19 - 20. Pridržavanje i kršenje ovdje se odnose na pojedince čije je ponašanje uvjet za akt prisile. Primjenjivanje (koje je često istodobno i obvezno pa predstavlja i pridržavanje) i neprimjenjivanje (koje predstavlja kršenje, ako je primjenjivanje kvalificirano kao obvezno) odnose se na ponašanje organa primjene prava, tj. na njihovo postavljanje pojedinačnih normi kojima se određuje da je određeni akt prisile obvezan (kada je riječ o sudovima i upravnim organima) i da ga se treba izvršiti (kada je riječ o organima izvršenja kao organima primjene prava).

49 Ibid., str. 20.

50 Ibid., str. 140.

51 Ibid., str. 20. 
Kada je riječ o općim normama, osim toga što su one uvjetno važeće, one su i samo posredno važeće. Budući da je opća norma važeća pod uvjetom da se nje može pridržavati ili je kršiti, i primjenjivati je ili ne primjenjivati, i budući da je se, kao što je objašnjeno u 2. poglavlju, može primjenjivati (i da se nje može pridržavati, ako je primjena kvalificirana kao obvezna) samo posredno ${ }^{52}$, tj. posredstvom primjene (i pridržavanja, ako je primjena kvalificirana kao obvezna) pojedinačne kategoričke norme koja odgovara općoj normi ${ }^{53}$, opća (hipotetič$\mathrm{ka})^{54}$ norma može se smatrati važećom samo pod uvjetom da je moguće da se u njoj apstraktno određen uvjet ostvari u konkretnom slučaju (tj. da je moguće da se prekrši opća implicitna norma o ponašanju), i da je moguće da se postavi odgovarajuća pojedinačna kategorička norma. ${ }^{55}$ Iako će, u pravilu, postavljanje odgovarajuće pojedinačne kategoričke norme koju sud upućuje samome sebi biti moguće, može se, barem teoretski, zamisliti slučaj u kojemu to ne bi bilo moguće, npr. ondje gdje ne postoje sudovi. Dakle, mogućnost učinkovitosti opće sankcionirajuće norme uvjetovana je i mogućnošću postavljanja odgovarajuće pojedinačne kategoričke norme. ${ }^{56}$ Opća (hipotetička) norma postaje potpuno važeća od trenutka od kojega je se stvarno može primjenjivati (ili se nje pridrža-

52 Čini se da se i pojedinci čije je ponašanje uvjet za akt prisile mogu opće hipotetičke sankcionirajuće norme pridržavati samo posredno, tj. posredstvom pridržavanja pojedinačne kategoričke norme koja odgovara implicitnoj općoj normi o ponašanju, koju je postavio takav pojedinac (tj. posredni adresat opće sankcionirajuće norme).

53 Kelsen, op. cit. u bilj. 1, str. 50.

54 Ovdje se ograničavam na opće hipotetičke norme jer su, barem u Kelsenovoj teoriji, opće pravne norme u njihovoj ispravnoj formulaciji hipotetičke norme ('Ako nadležni organ primjene prava utvrdi da..., on treba postaviti pojedinačnu normu...').

55 Ako se uzme da primjena opće norme završava izvršenjem akta prisile, dodatan bi uvjet bio da je moguće da se primijeni (ili se nje pridržava) ili neprimjeni (ili prekrši) pojedinačna norma kojom se organu izvršenja zapovijeda da izvrši akt prisile. Premda će u pravilu biti moguće da organi izvršenja izvrše akte prisile određene pojedinačnim kategoričkim sankcionirajućim normama koje su postavili sudovi, može se, barem teoretski, zamisliti situaciju u kojoj to ne bi bilo moguće, npr. ondje gdje ne postoje organi izvršenja. Međutim, iz Kelsenove 'ispravne' formulacije opće sankcionirajuće norme proizlazi da se primjena ove norme sastoji u postavljanju pojedinačne kategoričke sankcionirajuće norme, a ne u izvršenju njome određene sankcije. Čini se da je izvršenje određene sankcije primjena (pridržavanje) od organa izvršenja pojedinačne kategoričke sankcionirajuće norme koju je postavio nadležni organ primjene prava.

56 Naravno, trebalo bi biti moguće i da se takvu pojedinačnu kategoričku normu primijeni (da se nje pridržava) ili ne primijeni (prekrši). Međutim, ne mogu zamisliti slučaj u kojemu bi bilo općenito nemoguće da sudovi primjenjuju (pridržavaju se) ili ne primjenjuju (krše) odgovarajuće pojedinačne kategoričke norme koje postave. 
vati) ili ne primjenjivati (kršiti) ${ }^{57}$, to jest od trenutka postavljanja pojedinačne kategoričke norme koja odgovara općoj (hipotetičkoj) normi. ${ }^{58}$

Opća (hipotetička) norma stječe potpuno važenje kroz proces svoje individualizacije. ${ }^{59}$ Proces individualizacije počinje utvrđivanjem organa primjene prava (npr. suda) postoji li konkretno činjenično stanje podvedivo pod činjenično stanje apstraktno određeno u općoj normi. Ako sud utvrdi da konkretno činjenično stanje podvedivo pod činjenično stanje apstraktno određeno u općoj normi postoji, proces se nastavlja postavljanjem odgovarajuće pojedinačne kategoričke norme ' $\mathrm{Ti}$, nadležni sude, trebaš postaviti pojedinačnu normu kojom se određuje da se treba izvršiti određeni akt prisile’. Stoga, kaže Kelsen, “[v]aženje’ opće norme, tj. njezino specifično postojanje, nije statično stanje nego dinamičan proces". ${ }^{60}$ Važenje se razvija postupno, naime, od uvjetnog do potpunog važenja.

Sudsko postavljanje pojedinačne norme kojom se određuje da se treba izvršiti konkretan akt prisile podvediv pod akt prisile apstraktno određen u općoj normi pretpostavlja priznanje opće (hipotetičke) norme. Priznanje opće (hipotetičke) norme sastoji se u postavljanju pojedinačne kategoričke norme upućene nadležnom organu primjene prava, npr. nadležnom sudu. Prema Kelsenu postoje dva moguća slučaja priznanja. Ili sam nadležni sud priznaje opću (hipotetičku) normu koju treba primijeniti i sam sebi upućuje odgovarajuću pojedinačnu kategoričku normu ili viši sud priznaje opću (hipotetičku) normu koju nadležni

57 Nejasno je bi li Kelsen dopustio zaključak da opća sankcionirajuća norma postaje potpuno važeća čak i u slučaju kada njezin posredni adresat (pojedinac čije je ponašanje uvjet za akt prisile) postavi pojedinačnu kategoričku normu, upućenu samome sebi, koja odgovara općoj normi o ponašanju koja je implicirana općom sankcionirajućom normom. To se, međutim, ne čini dovoljnim jer bi pojedinac još uvijek mogao propustiti pridržavati se pojedinačne kategoričke norme koju si je uputio, što bi pak zahtijevalo primjenu opće sankcionirajuće norme. Stoga bi se u ovom slučaju trebalo tvrditi da opća sankcionirajuća norma postaje potpuno važećom ako pojedinac ne samo prizna implicitnu opću normu o ponašanju i postavi odgovarajuću pojedinačnu kategoričku normu, nego se, osim toga, nje i pridržava. No, to ne bi bilo u skladu ni s Kelsenovim kriterijem za potpuno važenje (koji ne traži pridržavanje odgovarajuće pojedinačne kategoričke norme) ni s njegovim shvaćanjem položaja i važnosti 'normi o ponašanju' u pravnom poretku.

58 Čini se da Navarro brka pojedinačnu kategoričku normu koju sud, priznajući opću normu, upućuje samome sebi s pojedinačnom normom koju sud upućuje organu izvršenja. To ga vodi k zaključku da je, prema Kelsenu, "opća norma važeća 'potpuno' važeća - samo ukoliko je primijenjena - što je isto što i reći da je norma potpuno važeća samo ako je učinkovita”. Vidi Navarro, op. cit. u bilj. 1, str. 99.

59 Vidi Kelsen, op. cit. u bilj. 1, str. 50.

Ibid. 
sud treba primijeniti (ali je nije priznao) i upućuje odgovarajuću pojedinačnu kategoričku normu nadležnom sudu. ${ }^{61}$

Naravno, moguće je i da nadležni sud ne prizna opću (hipotetičku) normu za konkretan slučaj i stoga ne postavi odgovarajuću pojedinačnu kategoričku normu upućenu samome sebi. Ako na njegovu odluku nije uložena žalba i ona postane res iudicata, opća (hipotetička) norma neće steći potpuno važenje za taj slučaj. ${ }^{62}$ Isto tako, opća (hipotetička) norma neće steći potpuno važenje ako je riječ o sudu posljednjeg stupnja i taj sud ne prizna opću (hipotetičku) normu koja treba biti primijenjena. ${ }^{63}$ Međutim, “činjenica da sud u konkretnom slučaju ne priznaje opću pravnu normu i zato je ne primijeni na taj slučaj ne ukida važenje te opće pravne norme pa je stoga isti sudac, a pogotovo drugi suci, mogu primijeniti kao važeću pravnu normu u sličnome slučaju". ${ }^{64}$

Dobro je ovdje navesti nekoliko primjera uvjetno i potpuno važećih normi.

1) Opća sankcionirajuća norma 'Ako nadležni sud utvrdi da je netko počinio ubojstvo, sud treba postaviti pojedinačnu normu kojom se organu izvršenja nalaže da nad tom osobom izvrši kaznu zatvora u trajanju 10 godina' uvjetno je važeća jer je važeća pod uvjetom da se nje može pridržavati ili je kršiti, te je primjenjivati ili ne primjenjivati, ili, konkretnije, da je moguće da netko počini ubojstvo (tj. da prekrši implicitnu opću normu kojom se zabranjuje ubojstvo), da nadležni sud utvrdi da je netko počinio ubojstvo i da sud samome sebi uputi odgovarajuću pojedinačnu kategoričku normu 'Ti, nadležni sude, trebaš postaviti pojedinačnu normu kojom se nalaže organu izvršenja da nad tom osobom izvrši kaznu zatvora u trajanju 10 godina' (što, posljedično, čini mogućom primjenu opće sankcionirajuće norme). Ta je norma potpuno važeća kada nadležni sud stvarno utvrdi da je, primjerice, Ivan počinio ubojstvo i stvarno samome sebi uputi odgovarajuću pojedinačnu kategoričku normu 'Ti, nadležni sude, trebaš postaviti pojedinačnu normu kojom se organu izvršenja nalaže da nad Ivanom izvrši kaznu zatvora u trajanju 10 godina', tj. ako je ostvaren uvjet pod kojim je norma važeća.

2) Pojedinačna kategorička sankcionirajuća norma 'Ti, organe izvršenja, trebaš nad Ivanom izvršiti kaznu zatvora u trajanju 10 godina', koju je postavio nadležni sud, uvjetno je važeća jer je važeća pod uvjetom da je se može primijeniti (nje se pridržavati) ili ne primijeniti (prekršiti), tj.

${ }_{61}$ Vidi ibid., str. 53 - 54 i 239.

62 Ibid., str. 53.

63 Ibid., str. 54.

64 Ibid. 
da je ovlašteno i zapovjeđeno ponašanje (tj. zatvaranje) moguće, ili, konkretnije, da postoji organ izvršenja i da je Ivan živ. Ta je norma potpuno važeća kada stvarno postoji organ izvršenja i Ivan je stvarno živ, tj. ako je ostvaren uvjet pod kojim je norma važeća.

3) Konačno, pojedinačna hipotetička sankcionirajuća norma 'Ti, nadležni organe izvršenja, trebaš nad Elizabetom izvršiti kaznu zatvora u trajanju 5 godina ako počini drugo kazneno djelo u iduće 3 godine ${ }^{65}$ uvjetno je važeća jer je važeća pod uvjetom da se nje može pridržavati ili je kršiti, i primjenjivati je i ne primjenjivati je, ili, konkretnije, da je moguće da Elizabeta počini drugo kazneno djelo u iduće 3 godine (mogućnost kršenja implicitne pojedinačne norme o ponašanju) ${ }^{66}$, da nadležni sud utvrdi da je počinila drugo kazneno djelo u tom razdoblju, da sud postavi pojedinačnu kategoričku normu kojoj se nalaže organu izvršenja da nad Elizabetom izvrši kaznu zatvora u trajanju 5 godina, da postoji organ izvršenja i da je Elizabeta živa. Ta je norma potpuno važeća kada nadležni sud stvarno utvrdi da je Elizabeta počinila drugo kazneno djelo u razdoblju od 3 godine, nadležni sud stvarno postavi pojedinačnu kategoričku normu kojom se organu izvršenja nalaže da nad Elizabetom izvrši kaznu zatvora u trajanju 5 godina, organ izvršenja stvarno postoji i Elizabeta je živa, tj. ako je ostvaren uvjet pod kojim je norma važeća.

Dakle, može se reći sljedeće:

1) Opća hipotetička sankcionirajuća norma uvjetno je važeća za sve moguće slučajeve nakon što je postavljena jer je važeća pod uvjetom de se nje može pridržavati ili je kršiti, i primjenjivati je ili ne primjenjivati, to jest ako je moguće da se u njoj apstraktno određen uvjet ostvari u konkretnom slučaju (mogućnost da posredni adresati prekrše implicitnu normu o ponašanju) i da bude postavljena odgovarajuća pojedinačna kategorička norma (što, posljedično, čini mogućom primjenu opće sankcionirajuće norme). Opća hipotetička norma je potpuno važeća za svaki pojedini slučaj ako je u njoj apstraktno određen uvjet ostvaren u konkretnom slučaju (tj. ako je posredni adresat opće hipotetičke norme

65 Naravno, ispravna formulacija bila bi '... ako nadležni sud utvrdi da je Elizabeta počinila drugo kazneno djelo ....

66 Prema analogiji s Kelsenovim shvaćanjem da su, pod pretpostavkom da zapravo postoje dvije različite vrste normi, naime, norme upućene pojedincima čije je ponašanje uvjet za sankciju (norme o ponašanju) i norme upućene organima primjene prava (sankcionirajuće norme), norme o ponašanju samo implicirane u sankcionirajućim normama, pojedinačne norme o ponašanju ovdje predočavam kao implicitne pojedinačne hipotetičke sankcionirajuće norme. 
prekršio implicitnu normu o ponašanju) i ako je postavljena odgovarajuća pojedinačna kategorička norma.

2) Pojedinačna kategorička sankcionirajuća norma uvjetno je važeća za pojedinačni slučaj nakon što je postavljena jer je važeća pod uvjetom da je se može primijeniti (nje se pridržavati) ili ne primijeniti (prekršiti), to jest da je sankcioniranje (tj. izvršenje akta prisile) moguće (tj. da je ostvaren uvjet za njezinu primjenu na subjekt akta prisile), a potpuno je važeća za pojedinačni slučaj ako je se stvarno može primijeniti (nje se pridržavati) ili ne primijeniti (prekršiti), to jest ako je sankcioniranje (tj. izvršenje akta prisile) stvarno moguće (tj. ako je ostvaren uvjet za njezinu primjenu na subjekt akta prisile). Kada je riječ o pojedinačnim kategoričkim normama, trenutak u kojemu one postaju uvjetno važeće i trenutak u kojemu one postaju potpuno važeće podudaraju se (tj. one su i uvjetno i potpuno važeće od trenutka njihova postavljanja).

3) Pojedinačna hipotetička sankcionirajuća norma uvjetno je važeća za pojedinačni slučaj nakon što je postavljena jer je važeća pod uvjetom de se nje može pridržavati ili je kršiti, i primjenjivati je ili ne primjenjivati, to jest ako je moguće da se u njoj apstraktno određen uvjet ostvari u konkretnom slučaju (tj. mogućnost da posredni adresat pojedinačne hipotetičke sankcionirajuće norme prekrši implicitnu pojedinačnu normu o ponašanju), da nadležni sud utvrdi da je uvjet ostvaren, i da postavi pojedinačnu kategoričku normu kojom se organu izvršenja nalaže izvršenje određene sankcije, a koja se može primijeniti (koje se može pridržavati) ili ne primijeniti (prekršiti). Pojedinačna hipotetička sankcionirajuća norma potpuno je važeća za pojedinačni slučaj ako nadležni sud utvrdi da je u njoj određen uvjet ostvaren (tj. ako je posredni adresat pojedinačne hipotetičke norme prekršio implicitnu pojedinačnu normu o ponašanju) i postavi pojedinačnu kategoričku normu koja se može primijeniti (koje se može pridržavati) ili ne primijeniti (prekršiti), a kojom se ovlašćuje i zapovijeda izvršenje u njoj određene sankcije.

Da zaključim. Mogućnost učinkovitosti kao uvjet početka pravnog važenja opće hipotetičke sankcionirajuće norme znači mogućnost pridržavanja ili kršenja implicitne opće norme o ponašanju i mogućnost primjene (pridržavanja) i neprimjene (kršenja) opće hipotetičke sankcionirajuće norme (koja mogućnost postoji ako postoji mogućnost da sudovi postavljaju odgovarajuće pojedinačne kategoričke norme). Mogućnost učinkovitosti kao uvjet početka pravnog važenja pojedinačne kategoričke sankcionirajuće norme znači mogućnost njezine primjene (pridržavanja) ili neprimjene (kršenja). Mogućnost učinkovitosti kao uvjet početka pravnog važenja pojedinačne hipotetičke sankcionirajuće norme znači 
mogućnost pridržavanja ili kršenja implicitne norme o ponašanju i mogućnost primjene (pridržavanja) ili neprimjene (kršenja) pojedinačne kategoričke sankcionirajuće norme koja je postavljena u skladu s pojedinačnom hipotetičkom sankcionirajućom normom.

\section{UČINKOVITOST KAO UVJET SVRŠETKA VAŽENJA NORME}

Prema Kelsenu norma prestaje biti važeća (tj. gubi svoje početno stečeno važenje) ako je se derogira, to jest ako je se ukine drugom normom, ako istekne vrijeme važenja za koje je postavljena i, kada je riječ o pojedinačnim normama, ako se normu izvrši. Međutim, kao i u slučaju početka važenja norme, i ovdje učinkovitost ima ulogu uvjeta važenja. Pravna norma gubi važenje ako izgubi "učinkovitost ili mogućnost učinkovitosti”. ${ }^{67}$ Učinkovitost je uvjet svršetka važenja norme. Preciznije, kada je riječ o općim pravnim normama, takva norma gubi važenje u sljedećim dvama slučajevima: 1) ako izgubi mogućnost učinkovitosti ili 2) ako izgubi učinkovitost. Kada je riječ o pojedinačnim pravnim normama, one gube važenje ako izgube mogućnost učinkovitosti. ${ }^{68}$

Mogućnost učinkovitosti, kao što je već rečeno, znači mogućnost pridržavanja ili primjenjivanja norme. Stoga, opća sankcionirajuća norma gubi važenje ako se nje više nije moguće pridržavati ili je primjenjivati. To može biti slučaj kada više nije moguće da se ostvari činjenično stanje apstraktno određeno općom sankcionirajućom normom koje je uvjet za akt prisile. Ponajprije je riječ o slučaju kada norma o ponašanju, koja je implicirana općom sankcionirajućom normom, izgubi mogućnost da se nje pridržava ili je se krši. Međutim, budući da se implicitne norme o ponašanju više nije moguće pridržavati ili je kršiti, ni opću sankcionirajuću normu se više ne može primjenjivati. Opću sankcionirajuću normu se ne može primjenjivati jer sud nikada neće doći u situaciju da utvrdi da je u konkretnom slučaju nastupilo činjenično stanje koje je apstraktno određeno kao uvjet za akt prisile. No, čak i ako implicitna norma o ponašanju ne bi izgubila mogućnost da se nje pridržava ili je se krši, opća sankcionirajuća norma izgubila bi važenje kada bi izgubila mogućnost da bude primijenjena. To bi se, barem teoretski, dogodilo kada bi se, nakon postavljanja opće sankcionirajuće norme, sudovi ukinuli.

${ }_{67}$ Kelsen, op. cit. u bilj. 1, str. 139.

68 Čini se da je u Čistoj teoriji prava, 2. izd., Kelsen tvrdio da je i kod pojedinačnih normi uvjet svršetka važenja gubitak učinkovitosti. Vidi Kelsen, op. cit. u bilj. 22, str. 213 i $207-208$. 
Pojedinačne pravne norme također gube važenje ako izgube mogućnost učinkovitosti. Pojedinačna kategorička sankcionirajuća norma gubi važenje ako ostane neprimijenjena sve dok je se više ne može primijeniti (premda njezino vrijeme važenja još nije isteklo ${ }^{69}$ (npr. ona gubi važenje ako ostane neprimijenjena do trenutka smrti osobe kojoj je izrečena kazna zatvora ili, barem teoretski, do trenutka ukidanja svih organa izvršenja u dotičnom pravnom poretku). ${ }^{70}$ Isto se odnosi i na pojedinačne hipotetičke sankcionirajuće norme. Pojedinačna hipotetička sankcionirajuća norma gubi važenje ako ostane neprimijenjena sve dok je se više ne može primijeniti (premda njezino vrijeme važenja još nije isteklo) (npr. ako, nakon što se uvjet određen u takvoj normi ostvari i nadležni sud postavi pojedinačnu kategoričku normu kojom se zapovijeda izvršenje akta prisile, prethodna norma ostane neprimijenjena do smrti osobe protiv koje je određen akt prisile ili, barem teoretski, do ukidanja svih organa izvršenja u dotičnom pravnom poretku).

Pojedinačna hipotetička sankcionirajuća norma gubi važenje i kada se pojedinačne norme o ponašanju, koja je implicirana u pojedinačnoj hipotetičkoj sankcionirajućoj normi, pridržavalo (npr. pojedinačna hipotetička sankcionirajuća norma kojom se određuje ovrha na $A$-ovoj imovini ako $A$ u roku dva tjedna ne plati 1000 eura $B$-u gubi važenje ako $A$ plati navedeni iznos novca $B$-u prije isteka toga roka). Međutim, čini se da to nije slučaj u kojemu norma gubi važenje zbog toga što je izgubila učinkovitost. Naime, ako se, po analogiji, uzme Kelsenovo shvaćanje da se opću sankcionirajuću normu može smatrati učinkovitom čak i ako je se nikada nije primijenilo, ali pod uvjetom da su se građani uvijek pridržavali u njoj implicirane norme o ponašanju, može se tvrditi da je pojedinačna hipotetička sankcionirajuća norma učinkovita čak i ako nikada nije primijenjena, pod uvjetom da se u njoj implicirane pojedinačne norme o ponašanju pridržavalo, premda je pojedinačna hipotetička sankcionirajuća norma na taj način izgubila važenje.

Poseban slučaj u kojem opće pravne norme gube važenje je kada izgube (ne mogućnost učinkovitosti, nego) učinkovitost. Riječ je o tzv. desuetudo (izobičajenje). Prema Kelsenu opće pravne norme gube važenje "kada ih se prestane u

69 Dodao sam ovaj uvjet Kelsenovoj izvornoj formulaciji gubitka mogućnosti učinkovitosti pojedinačnih normi kao uvjeta njihova važenja kako bih napravio razliku između situacije u kojoj pojedinačna norma gubi važenje jer je izgubila mogućnost učinkovitosti i situacije u kojoj gubi važenje jer je isteklo njezino vrijeme važenja, što Kelsen, kao što je naznačeno u 1. poglavlju, utvrđuje kao zaseban uvjet svršetka važenja norme.

70 Kelsen, op. cit. u bilj. 1, str. 139 - 140. 
cjelini gledano pridržavati, a kada ih se ne pridržava primjenjivati". ${ }^{71}$ Kelsen daje sljedeći primjer:

opća pravna norma kojom se zabranjuje prodaja alkoholnih pića tako što se njome određuje da se onoga tko ih prodaje treba kazniti zatvorom izgubila bi svoje važenje pokaže li se da je se zbog otpora subjekata koji su joj podvrgnuti ne pridržava, a ni nadležni je organi kod nepridržavanja ne primjenjuju. ${ }^{72}$

Postoje, dakle, dva uvjeta koja moraju biti ispunjena da bi se smatralo da je opća sankcionirajuća norma izgubila učinkovitost i, posljedično, svoje važenje. Prvo, da se posredni adresati opće sankcionirajuće norme općenito ('u cjelini gledano') ne pridržavaju implicitne opće norme o ponašanju i, drugo, da nadležni organi općenito ('u cjelini gledano') ne primjenjuju opću sankcionirajuću normu. Ne bi se smatralo da je norma izgubila učinkovitost kada se samo pojedinci čije je ponašanje uvjet za akt prisile određen u općoj sankcionirajućoj normi ne bi u cjelini gledano pridržavali implicitne norme o ponašanju, a nadležni bi organi istodobno u cjelini gledano primjenjivali opću sankcionirajuću normu.

Međutim, slijedeći ono što se čini Kelsenovim shvaćanjem o tome kada se normu može smatrati učinkovitom ${ }^{73}$, čini se da norma gubi učinkovitost čak i kada se nje u cjelini gledano pridržava, ako se, u slučaju njezina kršenja, bez obzira na razmjere toga kršenja, ona u cjelini gledano ne primjenjuje. Stoga se čini potrebnim ponešto precizirati gorenavedenu Kelsenovu tvrdnju o tome kada norma gubi svoju učinkovitost i, posljedično, svoje važenje. Norma gubi učinkovitost i, posljedično, važenje kada je se u cjelini gledano ne primjenjuje u slučajevima njezina nepridržavanja (kršenja), bez obzira na to je li se nje u cjelini gledano pridržavalo ili ne.

Općenito nepridržavanje sankcionirajuće norme od njezinih posrednih adresata (tj. adresata implicitne opće norme o ponašanju) i općenito neprimjenjivanje norme od nadležnih organa primjene prava tijekom duljeg razdoblja čini običaj. ${ }^{74}$ Prema Kelsenu postoje dva načina na koja takav običaj može dovesti do gubitka učinkovitosti norme i, posljedično, do gubitka njezina važenja. Prvi je kada običaj nepridržavanja i neprimjenjivanja nije popraćen nastankom norme o ponašanju uobičajenjem. ${ }^{75}$ Primjerice, da se poslužim gorenavedenom općom normom o prodaji alkoholnih pića, kada ljudi prodaju alkoholna pića, a nadležni organi

$71 \quad$ Ibid., str. 139.

72 Ibid.

73 Vidi 2. poglavlje.

74 Kelsen, op. cit. u bilj. 1, str. 109.

75 Ibid. 
ne utvrđuju da ljudi prodaju alkoholna pića i ne postavljaju pojedinačne kategoričke norme kojima se nalaže organima izvršenja da nad njima izvrše kaznu zatvora. Drugi je kada je takav običaj popraćen nastankom norme o ponašanju uobičajenjem. ${ }^{76} \mathrm{U}$ drugom slučaju, dotična norma može biti bilo "norma kojom se propisuje propuštanje neke radnje zapovjeđene dotad važećom normom bilo norma kojom se propisuje činjenje neke radnje čije je propuštanje zapovjeđeno nekom dotad važećom normom". ${ }^{77}$ Primjerice, kada, osim običaja nepridržavanja i neprimjenjivanja opće norme o prodaji alkoholnih pića, nastane nova (implicitna opća) običajna norma kojom se prodaja alkoholnih pića određuje kao obvezna, i nastane nova opća običajna sankcionirajuća norma kojom se obveznim određuje kažnjavanje zatvorom onih za koje nadležni organi utvrde da nisu prodavali alkoholna pića. Iako u drugom slučaju postoji nespojivost između onoga što kao obvezno određuju nova običajna norma i nepridržavana i neprimjenjivana postavljena (npr. zakonska) norma, zapravo ne postoji "nikakav sukob normi, jer uobičajenje, kojim nastaje nova norma, podrazumijeva trajno nepridržavanje i neprimjenjivanje dotad važeće norme, čime ona gubi svoju učinkovitost te time i svoje važenje" ${ }^{78}$ Prema tome, razlog gubitka učinkovitosti opće norme u obama je slučajevima trajno zbiljsko ponašanje koje proturječi normom određenom trebanom ponašanju. ${ }^{79}$

Dok Kelsen daje (pojmovni) argument za mogućnost učinkovitosti kao uvjet važenja ${ }^{80}$, u svojoj Općoj teoriji normi on samo stipulira da opća pravna norma gubi svoje važenje ako izgubi svoju učinkovitost. Stoga ću ispitati argumente koje Kelsen navodi u Čistoj teoriji prava i Općoj teoriji prava i države. Također, budući da je već nastanak običaja nepridržavanja i neprimjenjivanja norme (a ne i nastanak nove nespojive običajne norme) dovoljan da bi se smatralo da je

76 Ibid.

77 Ibid.

78 Ibid.

79 Običaj nepridržavanja i neprimjenjivanja ne može činiti derogirajuću običajnu normu. Prema Kelsenovu mišljenju “derogirajuća norma ne može nastati uobičajenjem”. Vidi ibid. Razlog tome je da se običajne norme mogu odnositi samo na ljudsko ponašanje (tj. one mogu biti samo norme o ponašanju), dok se derogirajuće norme odnose na važenje drugih normi. Vidi ibid., str. 106 - 107. Međutim, čini se da je Kelsen u svojim ranijim radovima dopuštao mogućnost postojanja derogirajućih običajnih normi. U Općoj teoriji prava i države kaže da “[d]esuetudo poništava normu stvarajući drugu normu, koja je po svojem karakteru istovjetna zakonu čija je jedina funkcija da ukine ranije važeći zakon". Vidi Kelsen, op. cit. u bilj. 16, str. 119.

Vidi 3. poglavlje. 
norma izgubila učinkovitost te time i važenje, usredotočit ću se na Kelsenovo objašnjenje zašto je to nužno tako.

Prema Kelsenu učinkovitost je određena kao uvjet važenja ustava, pravnog poretka u cjelini, i svake pojedine pravne norme u temeljnoj normi pravnog sustava. ${ }^{81}$

Razlog važenja - to jest, odgovor na pitanje zašto se normi toga pravnog poretka treba pridržavati i primjenjivati ih - jest pretpostavljena temeljna norma, prema kojoj treba postupati u skladu sa stvarno uspostavljenim, u cjelini gledano učinkovitim ustavom te, stoga, u cjelini gledano učinkovitim normama koje su stvarno postavljene sukladno tom ustavu. Postavljanje i učinkovitost su u temeljnoj normi učinjeni uvjetom važenja - "učinkovitost" u smislu što se ona mora pridružiti činjenici postavljanja kako ni pravni poredak kao cjelina ni pojedina pravna norma ne bi izgubili svoje važenje. ${ }^{82}$

Prema tome,

važećom se ne smatra norma koje se nikada ne pridržava ili je se ne primjenjuje. Zapravo, pravna norma može izgubiti važenje time što je se nikada ne primjenjuje ili se nje ne pridržava - na temelju tzv. desuetudo. Desuetudo se može opisati kao negativan običaj, i njegova se bitna funkcija sastoji u tome da ukine važenje neke postojeće norme. ... Ako je učinkovitost $\mathrm{u}$ ovdje razvijenom smislu uvjet važenja ne samo pravnog poretka kao cjeline nego i pojedine pravne norme, onda se pravostvarajuću funkciju običaja ne može isključiti postavljenim pravom, barem u mjeri u kojoj se to tiče negativne funkcije desuetudo. ${ }^{83}$

Kao što sam Kelsen priznaje, to je tumačenje valjano samo ako je učinkovitost uvjet važenja ne samo pravnog poretka kao cjeline nego i svake pojedine pravne norme pravnog poretka. A čini se da je, za Kelsena, to kontingentna stvar. Naime, ona ovisi o tome je li nešto poput međunarodnopravnog načela efektivnosti (prema kojemu "pravni poredak mora biti učinkovit da bi važio") $)^{84}$ "u određenoj mjeri usvojilo i državno pravo". ${ }^{85}$ Ako je takvo načelo usvojeno, "va-

81 Kelsen, op. cit. u bilj. 22, str. 208 i 212.

82 Ibid., str. 212.

83 Ibid., str. 213.

84 "Prema tom načelu međunarodnog prava, jedna stvarno uspostavljena vlast je legitimna vlada, prisilni poredak koji ta vlada propisuje je pravni poredak, a zajednica koju taj poredak čini je država u smislu međunarodnog prava u mjeri u kojoj je taj poredak, uzet u cjelini, učinkovit”. Kelsen, op. cit. u bilj. 16, str. 121.

85 Ibid., str. 122. 
ženje pojedine pravne norme se unutar državnog pravnog poretka može učiniti ovisnim o njezinoj učinkovitosti" u smislu desuetudo. ${ }^{86}$ Međutim, s jedne strane, ako je se formulira na taj način, učinkovitost je kontingentan uvjet važenja norme. S druge strane, Kelsen nije pokazao da je neki pravni poredak usvojio učinkovitost kao uvjet važenja u gorenavedenom smislu ili, još važnije, nije dao nijedan argument u pogledu toga zašto bi temeljna norma odredila učinkovitost kao uvjet važenja svake pojedine pravne norme, umjesto da se ograniči na opću učinkovitost pravnog poretka kao cjeline, što je dovoljno da bi se pretpostavila temeljna norma. Temeljna se norma, prema Kelsenu, “odnosi neposredno na određeni ustav, stvarno uspostavljen uobičajenjem ili postavljanjem, koji je u cjelini gledano učinkovit, a posredno na prisilni poredak stvoren u skladu s tim ustavom i koji je u cjelini gledano učinkovit". ${ }^{87}$

Nadalje, sam Kelsen, čini se, nudi drugi, pojmovno prikladniji, uvjet učinkovitosti kao uvjet svršetka važenja pojedine pravne norme, naime, gubitak učinkovitosti pravnog poretka kao cjeline.

Norme nekog pozitivnog pravnog poretka važe ... samo dok je taj pravni poredak učinkovit. Čim ustav izgubi učinkovitost, to jest, čim pravni poredak kao cjelina, utemeljen na tom ustavu, izgubi učinkovitost, pravni poredak i svaka pojedina norma gube svoje važenje. ${ }^{88}$

To je shvaćanje koje Kelsen izrijekom navodi u Općoj teoriji prava $i$ države, u kojoj tvrdi da se "[n] orma smatra važećom samo pod uvjetom da pripada sustavu normi, poretku koji je, u cjelini gledano, učinkovit" 99 i da "[s]vaka pojedina norma gubi važenje kada čitav pravni poredak kojemu ona pripada izgubi učinkovitost kao cjelina" ${ }^{90}$

Dakle, čini se da učinkovitost kao uvjet svršetka važenja pojedine pravne norme ne znači da pravna norma nužno gubi važenje ako izgubi učinkovitost ${ }^{91}$, nego, zapravo, ako pravni poredak kao cjelina prestane biti u cjelini gledano učinkovit. Budući da pravne norme postoje samo kao članovi sustava normi, one, prema definiciji, gube važenje kada sustav izgubi važenje. Nadalje, takav uvjet učinkovitosti kao uvjet svršetka važenja pravne norme dopušta postojanje važeće pravne norme čak i ako ona nije u cjelini gledano učinkovita ili je potpuno neučinkovita tijekom duljeg razdoblja sve dok postoji u cjelini gledano

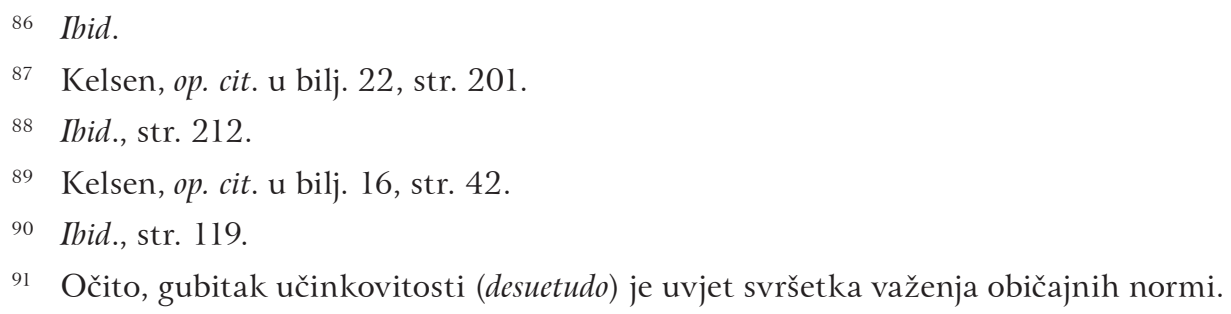


učinkovit pravni poredak, to jest sve dok postoji mogućnost da norma stekne (ako je potpuno neučinkovita od trenutka njezina postavljanja) ili nanovo stekne (ako je neučinkovita od nekog kasnijeg trenutka) svoju učinkovitost.

Dakako, može se tvrditi da bi norma izgubila svoje važenje gubitkom učinkovitosti u pravnom poretku u kojemu bi običaj bio uspostavljen kao pravostvarajuća činjenica. ${ }^{92}$ No, prema Kelsenu, ono što prekida važenje postavljene norme nije nova nespojiva običajna norma koja nastane uz staru i neučinkovitu postavljenu normu, nego običaj trajnog nepridržavanja i neprimjenjivanja postavljene norme. ${ }^{93}$ Prema tome, da bi norma izgubila važenje gubitkom učinkovitosti, desuetudo bi u dotičnom pravnom poretku trebao biti uspostavljen kao pravoukidajuća činjenica. Međutim, osim što pravni poredci u pravilu ne uređuju desuetudo, bilo bi nerazumno da to čine zbog toga što bi to značilo da bi istodobno zapovijedali organima primjene prava da primjenjuju važeće pravne norme i ovlašćivali ih da ih ne primjenjuju kada to ne žele i time okončaju njihovo važenje.

Iz toga proizlazi da opće pravne norme ustvari gube važenje ne kada izgube učinkovitost, nego, kao što je slučaj i s pojedinačnim pravnim normama, kada izgube mogućnost da budu učinkovite. Međutim, budući da one gube važenje i kada pravni poredak kao cjelina prestane biti u cjelini gledano učinkovit, naime, kada norme pravnog poretka postanu u cjelini gledano neučinkovite, može se reći da opća pravna norma gubi važenje kada dovoljan broj ostalih normi dotičnog poretka prestane biti učinkovit. Dakle, opća pravna norma gubi važenje ako izgubi mogućnost svoje učinkovitosti ili ako dovoljan broj ostalih normi dotičnog poretka izgubi svoju učinkovitost.

92 Vidi Kelsen, H., Reine Rechtslehre. Einleitung in die rechtswissenschaftliche Problematik, 1. izd., Leipzig, Wien, 1934., str. 73.

93 U Općoj teoriji prava i države Kelsen kaže da “[d]esuetudo poništava normu stvarajući drugu normu, koja je po svojem karakteru istovjetna zakonu čija je jedina funkcija da ukine ranije važeći zakon”. Vidi Kelsen, op. cit. u bilj. 16, str. 119. Prema tome, čini se da Kelsen dopušta postojanje derogirajućih običajnih normi. Međutim, u Općoj teoriji normi tvrdi da "derogirajuća norma ne može nastati uobičajenjem”. Vidi Kelsen, op. cit. u bilj. 1, str. 109. Razlog je taj što se običajne norme mogu odnositi samo na ljudsko ponašanje (tj. one mogu biti samo norme o ponašanju), dok su derogirajuće norme metanorme, koje se odnose na važenje drugih normi. Vidi ibid., str. $106-107$. 


\section{ZAKLJUČAK}

Prema Kelsenu učinkovitost je uvjet važenja pravnih normi. Međutim, iz analize i rekonstrukcije Kelsenovih shvaćanja iz Opće teorije normi slijedi da u slučaju normi postavljenih zakonodavstvom uvjet važenja norme zapravo nije učinkovitost norme, nego mogućnost njezine učinkovitosti. Proizlazi da je mogućnost učinkovitosti norme uvjet važenja i početka i svršetka važenja norme, osim u slučaju u kojem pravna norma gubi važenje kada dovoljan broj ostalih normi dotičnog poretka izgubi učinkovitost.

Konkretnije, uzimajući u obzir dinamički aspekt pravnog poretka, različite vrste pravnih normi, razlikovanje između uvjetnog i potpunog važenja norme i razlikovanje između pridržavanja i primjenjivanja norme, analiza i rekonstrukcija Kelsenova shvaćanja o učinkovitosti kao uvjetu važenja norme vodi k sljedećim zaključcima.

1) Opća hipotetička sankcionirajuća pravna norma stječe važenje kada je se postavi, pod uvjetom da se je moguće pridržavati u njoj implicirane opće norme o ponašanju ili je kršiti, i primjenjivati (pridržavati se je) i ne primjenjivati (kršiti) opću hipotetičku sankcionirajuću normu (koja pretpostavlja mogućnost da organi primjene prava postavljaju odgovarajuće pojedinačne kategoričke norme). Ona je važeća dok je se ne derogira, ili dok ne istekne njezino vrijeme važenja, ili dok u njoj implicirana opća norma o ponašanju ne izgubi mogućnost da se nje pridržava ili je se krši, ili dok opća sankcionirajuća norma ne izgubi mogućnost da bude posredno primijenjena, ili dok dovoljan broj ostalih normi dotičnog poretka ne izgubi mogućnost da se njih pridržava ili ih se primjenjuje.

2) Pojedinačna hipotetička sankcionirajuća pravna norma stječe važenje kada je se postavi, ili na temelju načela res iudicata (ako nije postavljena u skladu s općom sankcionirajućom normom), pod uvjetom da je moguće pridržavati se u njoj implicirane pojedinačne norme o ponašanju ili je kršiti, i primijeniti (ispoštovati) ili ne primijeniti (prekršiti) pojedinačnu kategoričku sankcionirajuću normu postavljenu u skladu s pojedinačnom hipotetičkom sankcionirajućom normom. Ona je važeća dok je se ne derogira, ili dok ne istekne njezino vrijeme važenja, ili dok se ne ispoštuje u njoj implicirana pojedinačna norma o ponašanju, ili dok je se ne izvrši, ili dok ne izgubi mogućnost da bude primijenjena (premda njezino vrijeme važenja još nije isteklo).

3) Pojedinačna kategorička sankcionirajuća pravna norma stječe važenje kada je se postavi, ili na temelju načela res iudicata (ako nije postavljena u skladu s općom sankcionirajućom normom), pod uvjetom da ju je moguće 
primijeniti (ispoštovati) i ne primijeniti (prekršiti). Ona je važeća dok je se ne derogira, ili dok ne istekne njezino vrijeme važenja, ili dok je se ne izvrši, ili dok ne izgubi mogućnost da bude primijenjena (premda njezino vrijeme važenja još nije isteklo).

\section{POPIS LITERATURE}

Luka Burazin, The Concept of Law and Efficacy, u: M. Sellers, S. Kirste (ur.), Encyclopedia of the Philosophy of Law and Social Philosophy, Springer, Dordrecht, 2017., str. 1-7.

Andrzej Grabowski, Juristic Concept of the Validity of Statutory Law. A Critique of Contemporary Legal Nonpositivism, prevela Małgorzata Kiełtyka, Springer, Berlin, Heidelberg, 2013.

Riccardo Guastini, Le fonti del diritto, A. Giuffrè editore, Milano, 2010.

Hans Kelsen, Reine Rechtslehre. Einleitung in die rechtswissenschaftliche Problematik, 1. izd., Leipzig, Wien, 1934.

Hans Kelsen, General Theory of Law and State, preveo Anders Wedberg, Cambridge, Massachusetts, Harvard University Press, 1945.

Hans Kelsen, Pure Theory of Law, 2 izd., preveo Max Knight, University of California Press, Berkeley and Los Angeles, 1967.

Hans Kelsen, General Theory of Norms, preveo M. Hartney, Clarendon Press, Oxford, 1991.

Pablo E. Navarro, The Efficacy of Constitutional Norms, u: L. D. d'Almeida, J. Gardner, L. Green (ur.), Kelsen Revisited. New Essays on the Pure Theory of Law, Hart Publishing, Oxford and Portland, Oregon, 2013., str. 77-99. 
Summary

\section{Luka Burazin*}

\section{EFFICACY AS A CONDITION OF VALIDITY IN HANS KELSEN'S GENERAL THEORY OF NORMS}

According to Kelsen, there are two (factual) conditions under which one can say that a legal norm is to (or ought to) be observed, and if not observed, then applied, i.e., that a norm exists or is valid. These are: 1) the fact that a norm has been posited (and has not been repealed), and 2) the fact that a norm is efficacious or that it has the possibility of being efficacious. The paper focuses on the second of the two (factual) conditions of validity. Its main aim is to reconstruct and critically analyse efficacy as a condition of validity in Hans Kelsen's General Theory of Norms both in the light of his newly introduced distinction between the conditional and full validity of a norm and the dynamic aspect of the legal order. It also aims to give a systemic account of efficacy as a condition of validity of both general and individual legal norms, taking into account the temporal aspect of validity, i.e., the moments in which a norm becomes valid and ceases to be valid, and the time span during which it remains valid.

The paper first outlines Kelsen's understanding of the concept of efficacy (Section 2). It then analyses and reconstructs the efficacy condition as a condition for the beginning of a legal norm's validity (Section 3), and goes on to analyse and reconstruct the efficacy condition as a condition of the end of a legal norm's validity. Finally, the paper systematizes the conditions under which the general hypothetical sanction-decreeing legal norm and the individual hypothetical and categorical sanction-decreeing legal norms acquire and lose their validity (Section 5).

Keywords: Hans Kelsen; validity; existence; efficacy; legal order

* Luka Burazin, Ph. D., Associate Professor, Faculty of Law, University of Zagreb, Trg Republike Hrvatske 14, 10000 Zagreb, Croatia; lburazn@pravo.hr;

ORCID: orcid.org/0000-0002-2437-8871 